\title{
Elemental composition of air masses under different altitudes in Azores, central north Atlantic
}

\author{
B. J. Vieira $・$ M. C. Freitas $\cdot$ H. Th. Wolterbeek
}

Received: 14 June 2011 / Published online: 1 July 2011

(C) Akadémiai Kiadó, Budapest, Hungary 2011

\begin{abstract}
Between 8th July 2002 and 18th June 2004, aerosol samples were collected in Azores. Their inorganic composition was obtained by neutron activation analysis in order to study the differences of aerosols in two atmospheric altitudes of the central north Atlantic: (1) PICONARE observatory (Lower Free Troposphere-LFT) at Pico mountain summit $\left(38,470^{\circ} \mathrm{N}, 28,404^{\circ} \mathrm{W}, 2,225 \mathrm{~m}\right.$ a.s.l.) in Pico Island, Azores, where air masses from the surrounding continents (Africa, Europe, Central and North America) pass through, carrying aerosols with anthropogenic $(\mathrm{Sb}, \mathrm{Br}$, $\mathrm{Mo}, \mathrm{U}, \mathrm{Se}$ and $\mathrm{Tb}$ ) and/or natural emissions (Fe, $\mathrm{Co}, \mathrm{La}$, $\mathrm{Na}, \mathrm{Sm}, \mathrm{Cr}, \mathrm{Zn}, \mathrm{Hf}, \mathrm{K}$ and Th); (2) TERCEIRA-NARE station (Marine Boundary Layer) at Serreta $\left(38,69^{\circ} \mathrm{N}\right.$, $27,36^{\circ} \mathrm{W}, 50 \mathrm{~m}$ a.s.1.), in Terceira Island, Azores, where natural aerosols (I, Cl, Na, Br and other soil related elements) are predominant. However, a combined interpretation of the data points out to a co-existence of the anthropogenic elements $\mathrm{Sb}$ and Mo, eventually with similar origins as the ones passing Pico Mountain summit. Very high concentrations and enrichment factors for $\mathrm{Sb}$, Mo and $\mathrm{Br}$ in LFT, higher than the ones found in other areas, confirm atmospheric long-range transport mainly from the west boundary of north Atlantic; this may indicate eventual accumulation and persistence of those elements in the area due to the presence of Azores high pressures or the Hadley
\end{abstract}

B. J. Vieira $(\square) \cdot$ M. C. Freitas

Instituto Tecnológico e Nuclear (ITN), URSN, Estrada Nacional 10, 2686-953 Sacavém, Portugal

e-mail: bvieira@itn.pt

B. J. Vieira $\cdot$ H. Th. Wolterbeek

Department of Radiation, Radionuclides and Reactors, Section

RIH (Radiation and Isotopes in Health), Faculty of Applied

Sciences, Technical University Delft, Mekelweg 15, 2629 JB

Delft, The Netherlands cells effect. A significant correlation between $\mathrm{Fe}$ and $\mathrm{Yb}$ and the enrichment of rare earth elements ( $\mathrm{La}, \mathrm{Sm}, \mathrm{Tb}$ and $\mathrm{Yb}$ ) and Th in LFT aerosols, both reflect a mineral dust intrusions from north Africa (Sahara and Sahel region).

Keywords NAA $\cdot \mathrm{k}_{0}$ INAA $\cdot$ Aerosol $\cdot$ Atmosphere . North Atlantic · Marine boundary layer (MBL) .

Free troposphere (LFT)

\section{Introduction}

The last few decades have witnessed an increased interest in the occurrence, magnitude and distributions of natural and anthropogenic aerosols. This is due to their known direct and indirect effects on the earth's climate and thus their influence on the earth-ocean-atmosphere system [16], and to the role that the aerosol particles may have on human health $[7,8]$.

The atmospheric aerosol contributes to about $10^{-9}-10^{-7}$ of the air mass, with $80 \%$ of the mass in the troposphere; more than half of its mass is concentrated in the first $5 \mathrm{~km}$ layer [9]. In the North Atlantic it is estimated that about $96 \%$ of the total aerosol emissions are from natural emissions: marine salt, biogenic elements and natural mineral dust. Volcanic emission is also significant. The remaining $4 \%$ result from long-range transport anthropogenic emissions, including biomass combustion, fossil combustion and other anthropogenic indirect activities [10]. The marine aerosol is characteristic of north Atlantic atmosphere, but its appearance is restricted to the marine boundary layer (MBL) that ranges altitudes between 850 and 2,000 m, depending on the latitude and the annual period. In Azores area, in summer, MBL ranges between 850 and $1,100 \mathrm{~m}$ and in winter between 900 and 1,700 m [11-13]. The 
composition of marine aerosol usually reflects the composition of seawater at the surface layer of the oceans; it is usually associated with larger water fractions, which results in physical changes as volume modification, aerodynamic diameter and optical properties. Therefore the marine aerosol easily changes its chemical composition by reacting with components of other sources [14, 15]. Marine aerosol in north Atlantic is commonly associated to high concentration of sulphur probably originated from biogenic, anthropogenic and volcanic (observed on the Atlantic Midridge) emissions [5, 16]. Mineral aerosol has the dust of Sahara and the Sahel region, both in north Africa, as its main source, contributing with approximately half of all mineral aerosols observed in the north Atlantic atmosphere [17-21]. The altitude of the dust layer could reach up to $6 \mathrm{~km}$, but over the central Atlantic ocean it is developed mainly in the first $4 \mathrm{~km} \mathrm{[18].} \mathrm{Silicate} \mathrm{is} \mathrm{the} \mathrm{most} \mathrm{abundant}$ particle type (65-85\%); however dust also carries large amounts of other elements (REE, $\mathrm{Al}, \mathrm{Ca}, \mathrm{Fe}, \mathrm{Sc}$ and $\mathrm{Sm}$ ) $[20,21]$. Dust from Sahara/Sahel region could also transport particles with origin other than the geological one. High enrichment factors of some pollutant elements (sulphur) in dust from Sahara/Sahel suggest a mixing process of the pollution aerosols from Europe with the mineral aerosols [18]. With particular weather conditions dust from arid and semi-arid regions of central Asia could also reach the north Atlantic, through the dust transported over Greenland [22]. Volcanic emissions also contribute with significant impact to the mineral emissions in north Atlantic. In the Azores area volcanoes from the midAtlantic ridge are mainly basaltic, with magmas rich in $\mathrm{Mg}$ and $\mathrm{Fe}$ and poor in $\mathrm{Si}$ [23]. The western and eastern boundaries of north Atlantic are extremely industrialized and urbanized, contributing by long-range transport to the aerosol increment. Among the anthropogenic emissions, biomass combustion is one of the most important sources of aerosols. The seasonality of concentrations of aerosols from biomass combustion on north Atlantic depends on the source area. During summer months in the Boreal forest of north America and south Europe forest fires occur, bringing carbonaceous aerosols and other particles to the north Atlantic [24, 25]. Some plums from Siberian forests have also been reported as reaching the north Atlantic [26]. In winter period, in Florida Peninsula, particular episodes of dry weather favor the increase of forest fires [27]. It is also during winter that aerosols from biomass combustion are higher in Europe mainly because of the fossil combustion for heating [26].

In general, aerosols reach the central north Atlantic in different vertical layers, depending of the air mass origins and aerosol characteristics [28]. However mechanisms of mass compensation could favor the penetration of particles in the anticyclone and their deposition over the central north Atlantic. The maximum annual aerosol concentrations are in summer [19,27].

This study intends to discuss elemental concentrations in air masses, which reached the central north Atlantic (Azores archipelago) in both Lower Free Troposphere (LFT) and MBL from 2002 to 2004. The climate of the archipelago is strongly influenced by the Azores anticyclone and the north Atlantic drift of the Gulf Stream, with high humidity and precipitation, which induce much milder temperatures than in other regions of the same latitude with similar oceanic temperate climate. The LFT site $(2,225 \mathrm{~m})$ is the PICO-NARE observatory in Pico Mountain in Pico Island which is the Portuguese highest peak placed in the Atlantic ocean. The MBL site (50 m high) is TERCEIRANARE station which is located in the western coast of Terceira Island, at $100 \mathrm{~m}$ from the coast line. TERCEIRANARE station is $100 \mathrm{~km}$ away from PICO-NARE observatory, based on their longitudes.

\section{Experimental}

In PICO-NARE station, the aerosol samples with particles of all ranges of aerodynamic diameters were continuously collected in quartz filters (manufacturer: Pallflex ${ }^{\circledR}$; type: Q250F) by the automated, self-contained Aethalometer (model AE31), for periods of approximately $24 \mathrm{~h}$, from 8th July 2002 to 18 th June 2004. The number of analyzed filters-384 filters-corresponds to an irregular periodicity ( $27 \%$ in spring, $41 \%$ in summer, $20 \%$ in autumn, $12 \%$ in winter). Furthermore, the collected air volumes varied between 0.21 and $80.9 \mathrm{~m}^{3}$. The average of the collected air volume and the average of the flow rate were, respectively $4.31 \pm 0.07 \mathrm{~m}^{3}$ and 3.3 L. $\mathrm{min}^{-1}$ between 8th July 2002 and 17th September 2003, and $8.47 \pm 0.44 \mathrm{~m}^{3}$ and $5.9 \mathrm{~L}$. $\mathrm{min}^{-1}$ between 18th September 2003 and 18th June 2004. Due to the remote setting of PICO-NARE and local weather conditions, instrumental maintenance was performed twice a year only [29].

At TERCEIRA-NARE station, aerosol particles below $2.5 \mu \mathrm{m}$ in diameter $\left(\mathrm{PM}_{2.5}\right)$ were weekly (7-day samples) collected on pre-fired quartz fibre filters with a high volume sampler, from 8th July 2002 to 22th June 2004, the same collection period of PICO-NARE station. The total number of analyzed filters is 62 filters, corresponding to some interruptions between October 2002 and June 2004. The average of the collected air volume was $10.1 \pm 3.1 \mathrm{~m}^{3}$.

The filters from PICO-NARE station (blanks and samples) were cut from the strips; each filter presented a circular form with an area of $0.950 \pm 0.086 \mathrm{~cm}^{2}$. Portions of the filters from TERCEIRA-NARE (blanks and samples) were cut. The samples and blanks were analysed by neutron activation analysis. For that, they were put into 


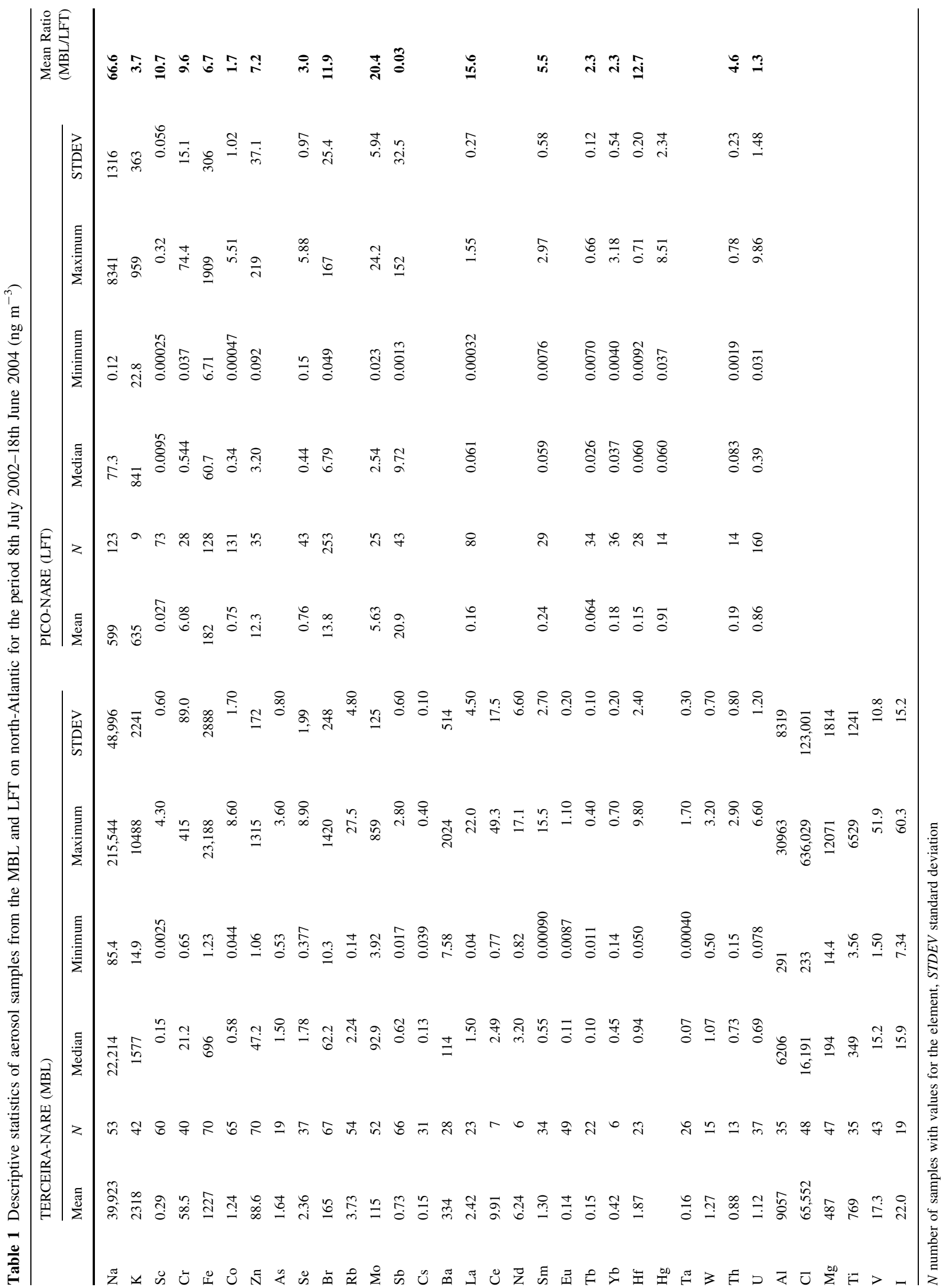


aluminium foil and irradiated with discs of an $0.1 \% \mathrm{Au}-\mathrm{Al}$ alloy (125 $\mu \mathrm{m}$ thick; $5 \mathrm{~mm}$ diameter) as comparators. The irradiation time was $7 \mathrm{~h}$ with a neutron thermal flux of $3 \times 10^{12} \mathrm{~cm}^{-2} \mathrm{~s}^{-1}$. After irradiation, the aluminium foils were removed, the samples and blanks decayed for 4-6 days and 4 weeks and each time were measured for $7 \mathrm{~h}$. The gold alloy discs were measured for $5 \mathrm{~min}$, also with the same detector, 7 days after the end of the irradiations. Short irradiations with neutron thermal flux of $6 \times 10^{11} \mathrm{~cm}^{-2} \mathrm{~s}^{-1}$ were also done in the TERCEIRANARE filters. All gamma spectra measurements were done using liquid nitrogen cooled hyperpure germanium detector (1.8 keV resolution at $1.33 \mathrm{MeV}$ and $30 \%$ relative efficiency), connected to 4,096 multi-channel analyzers. The elemental composition of the filters was calculated with the $\mathrm{k}_{0}$-IAEA software [30-34]. The reference material "Air Particulate on Filter Media" (NIST-SRM ${ }^{\circledR} 2783$; PM2.5 on a polycarbonate filter membrane) was analysed following the same procedure; the accuracy was within 5-15\% [36].

The enrichment factor (EF) of the chemical element $X$ in the aerosols relatively to the soil was calculated using $\mathrm{Sc}$ as the normalizing element and the composition of the soil collected at a depth below $0-10 \mathrm{~cm}$ at the same site [35], according to the expression: $\mathrm{EF}_{x}=[X / \mathrm{Sc}]_{\text {filter }} /[X / \mathrm{Sc}]_{\text {soil }}$.

STATISTICA $^{\circledR}$ StatSoft Inc. 8.0 was applied for exploratory, correlation and multivariate data analyses.

HYSPLIT software [37] was applied to obtain backtrajectories of air masses.

\section{Results and discussion}

Table 1 shows the elemental concentrations at PICONARE and TERCEIRA-NARE; concentrations of 19 and 33 chemical elements could be determined respectively. In both layers-LFT and MLB, high amplitudes of concentrations during the sampling period were found, except for the concentrations of Al, As, Cs, I, K, Sb, Se, Tb, Th, V, W, $\mathrm{Yb}$ in MBL, and $\mathrm{K}$ in LFT, all with low variances.

Based on the 10 days backtrajectories of the sampling days, the following was observed: (1) in LFT, the origin of the air masses are attributed to long-range transport from north-America (49\%), Arctic (12\%), local marine area (10\%), Europe (9\%), central America (9\%), Tropic-Cancer $(7 \%)$, and Africa (3\%); (2) in MBL, the origin of the air masses is mainly from local marine area (90\%), TropicCancer (8\%) and Europe (2\%). These distinct characteristics could explain the high ratios between the element concentrations averages of the two layers. With the exception of $\mathrm{Sb}$, all elements have higher mean concentrations in MBL than in LFT. Sodium concentration is almost two orders of magnitude higher in MBL than in LTR which was expected due to the closeness to the ocean and it is in accordance to reported values in other studies in oceanic areas and different altitudes. Other elements which are one order of magnitude higher in MBL than in LTR are $\mathrm{Sc}, \mathrm{Br}, \mathrm{Mo}$, La and Hf. On other hand, Sb which has much higher concentration in LFT, may be due to the accumulation of anthropogenic aerosol undergoing long-range transport in the LFT layer Fig. 1.

The daily aerosol concentrations of PICO-NARE were weekly averaged according the week sampling periods of TERCEIRA-NARE. Correlation analysis between data of both stations show no significant correlations (not shown), suggesting that the air masses in both LFT and MBL have different element enrichments sources. However, it may also be due to the fact that in LFT and MBL all particle sizes and the particles below $2.5 \mu \mathrm{m}$ were collected respectively. Enrichment factors were calculated to assess the elements with other origin than the crustal one and are

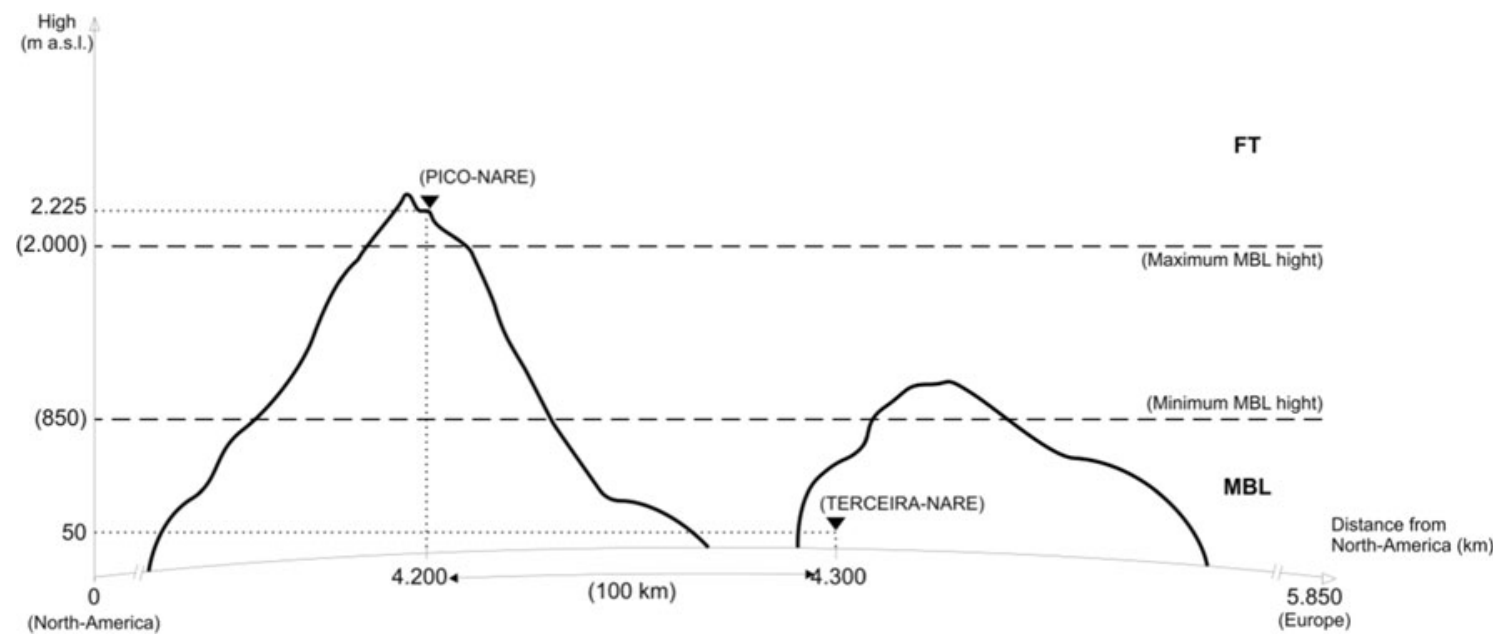

Fig. 1 Representation of the experimental stations in the context of north-America and Europe boundaries and of the atmosphere layers 

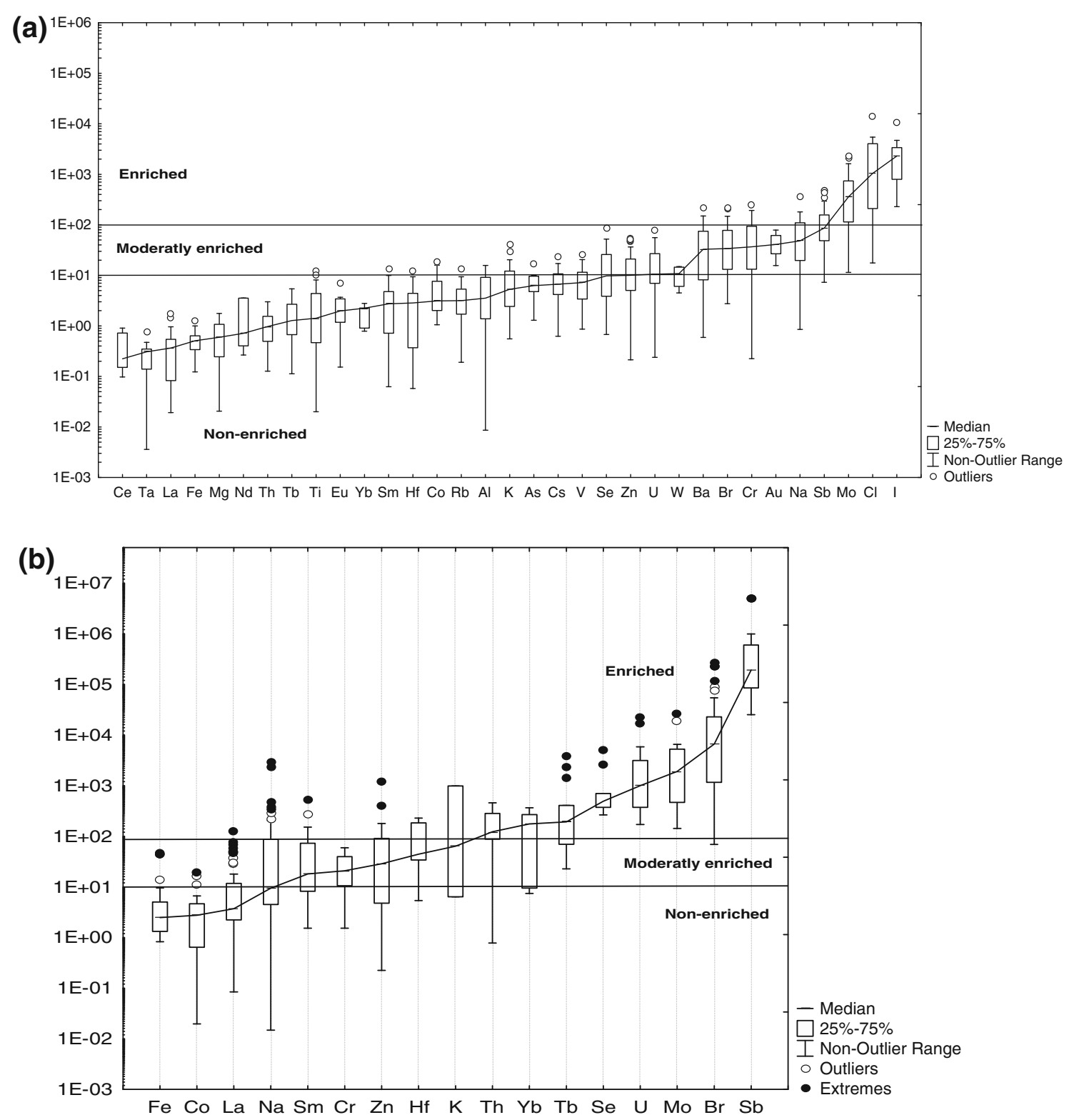

Fig. 2 The bar in the middle of each box represents the median of the data. The range of the box is from the 25 to 75 percentile. The whiskers extend from 10 up to 90 percentile. Points above the 90 percentile are plotted individually as outliers. a Crustal enrichment

shown in Fig. 2. Considering that the concentration data show high variability, the graphic presentation identifies the amplitude between 25 and $75 \%$ of the EF values on the non-outlier range, the outliers and the extreme values. In this approach we focus on the mean, further publications will discuss the events related with the extreme values. The EF factors below 10 are considered to show a strong correlation to the crustal signature. The EFs between 10 and 100 indicate a moderate enrichment above crustal levels and EFs above 100 indicate that the element is significantly enriched and is originated from other natural or anthropogenic emissions. factors relative to Scandium in MBL (TERCEIRA-NARE) at $50 \mathrm{~m}$ a.s.l. b Crustal enrichment factors relative to Scandium in LFT (PICO-NARE) at 2,225 $\mathrm{m}$ a.s.1

Concerning the MBL, the elements $\mathrm{Cl}$, I and Mo show high $\mathrm{EFs}$ and $\mathrm{Au}, \mathrm{Ba}, \mathrm{Br}, \mathrm{Cr}, \mathrm{Na}$, Sb have moderate EFs. $\mathrm{Br}, \mathrm{Cl}$, I, and $\mathrm{Na}$ have potential marine origin. Some studies refer some photoreactions and low residence times in the atmosphere that explain these results [38]. The $\mathrm{Sb}$ values are moderately enriched, however in some sporadic events the extreme values reflect an enrichment of 2 or 3 order of magnitude, suggesting depositions from LFT coming from high altitude long-range transport processes. $\mathrm{Sb}$ may also be due to local traffic.

In LFT, with exception of $\mathrm{Co}, \mathrm{Fe}$ and $\mathrm{La}$, all other elements present EF above 100. Nevertheless, only Br, Mo, 
Table 2 Element concentrations (ng. $\mathrm{m}^{3}$ ) with EF higher than 100 in MBL and LFT, and in other remote and urban areas

\begin{tabular}{|c|c|c|c|c|c|c|c|}
\hline & \multicolumn{2}{|l|}{ This study } & \multicolumn{3}{|l|}{ Remote area } & \multicolumn{2}{|l|}{ Urban area } \\
\hline & PICO-NARE & TERCEIRA-NARE & $\begin{array}{l}\text { Himalayan } \\
\text { Pakistan }\end{array}$ & $\begin{array}{l}\text { Bering sea } \\
\text { Artic }\end{array}$ & $\begin{array}{l}\text { Mace head } \\
\text { Ireland }\end{array}$ & $\begin{array}{l}\text { New York } \\
\text { state USA }\end{array}$ & $\begin{array}{l}\text { Lisbon } \\
\text { Portugal }\end{array}$ \\
\hline $\mathrm{Sb}$ & $20.9 \pm 32.5$ & - & 0.54 & 0.206 & & 0.4 & 2.3 \\
\hline $\mathrm{Br}$ & $13.8 \pm 25.4$ & - & & 1.416 & & 1.7 & 13.4 \\
\hline $\mathrm{U}$ & $0.86 \pm 1.48$ & - & & 0.178 & & 0.010 & \\
\hline $\mathrm{Se}$ & $0.76 \pm 0.97$ & - & 2.35 & & & 0.91 & 17.4 \\
\hline $\mathrm{Tb}$ & $0.064 \pm 0.12$ & - & & 0.007 & & 0.058 & \\
\hline Th & $0.19 \pm 0.23$ & - & 1.45 & 0.112 & & 0.012 & \\
\hline Mo & $5.63 \pm 5.94$ & $115 \pm 125$ & & 0.090 & & 0.20 & \\
\hline I & - & $220 \pm 15.2$ & & & 36.2 & & 2.6 \\
\hline $\mathrm{Cl}$ & - & $65,000 \pm 123,000$ & 692 & 1585 & & 25 & 930 \\
\hline
\end{tabular}

$\mathrm{Sb}, \mathrm{Se}, \mathrm{Tb}, \mathrm{Th}, \mathrm{U}$, and $\mathrm{Yb}$ are highly enriched. The EF values of $\mathrm{Br}$ and $\mathrm{Sb}$ reach 1,00,000, putting in evidence the large influence of anthropogenic emissions from polluted areas reaching the Azores area; the contamination levels are higher than in some highly polluted areas, reflecting some type of accumulation process. This phenomenon was previously referred by Freitas et al. [39]. Comparing the minimum and maximum EF values, Br concentrations with higher amplitude than the $\mathrm{Sb}$ ones could mean that they are more related with particularly emission events, while $\mathrm{Sb}$ values suggest background enrichment. An identical trend is observed for Se. Fossile combustion and traffic, both long transported, may be the origin [39, 40].

The magnitude of the enrichment between the two layers is different, except for Mo and Sb both with high enrichment. This fact puts in evidence the possibility of aerosol co-existence and same origins.

Table 2 shows the concentrations of the elements that are enriched in both layers and the concentrations of these elements in other remote and urban areas. Comparing to total suspended particles at remote site such Himalayan Mountains (Pakistan) [41] or Bering Sea (Arctic) [42] the concentrations at PICO-NARE are two orders of magnitude higher for Mo and $\mathrm{Sb}$, one order of magnitude higher for $\mathrm{Br}$ and $\mathrm{Tb}$ and similar magnitudes for $\mathrm{U}$. Se and Th concentrations are lower in PICO-NARE when compared with other remote areas. Mo and $\mathrm{Sb}$ have higher concentrations in this location (one order of magnitude) even when compared with urban areas of north America [43] and Europe [44].

In TERCEIRA-NARE, high concentrations of $\mathrm{Cl}$ and I confirm the marine suspended aerosols which influences the atmosphere at this altitude. Concentrations of Mo are even higher than in PICO-NARE, but lower EFs points out a crustal influence.

All the extreme concentration values observed in the enriched elements in LFT occur in summer season, particularly between July and August, in agreement with other authors which identify high aerosol concentrations during summer [19, 45, 46]. On other hand, concentration values of high enriched elements in MBL were identified in winter season, particularly during March and October, when the weather conditions favor the suspension of marine aerosols from ocean surface.

\section{Conclusions}

In the LFT, the air masses were classified as contaminated by anthropogenic elements coming from north-America and Europe, taking into account the aerosol enrichment in some trace elements and their high concentrations when compared with similar data from moderately-polluted urban and industrialized areas of North Atlantic coastal areas of Europe and America continents. Very high concentrations and EFs for $\mathrm{Br}$, Mo and $\mathrm{Sb}$, higher than in other globe areas, confirm atmospheric long-range transport, mainly from the western boundary of north Atlantic, not only by the direct plume transport from those extremely industrialized and urbanized areas, but indirectly via a possible accumulation and persistent emission of those elements in the area, due to the presence of Azores high pressures or the Hadley cells. Europe also contributes with similar components, with lower frequency due to the preferential wind directions from west. An additional contibution, even with less predominance, is related to mineral dust intrusions from north Africa (Sahara and Sahel region) with the enrichment of some typical elements as the rare earth elements ( $\mathrm{La}, \mathrm{Sm}, \mathrm{Tb}$ and $\mathrm{Yb}$ ) and $\mathrm{Th}$.

Based on EF values, the MBL is mainly dominated by marine elements ( $\mathrm{Br}, \mathrm{Cl}$, I, and $\mathrm{Na}$ ) and local suspended soil particles. This cleaner layer of atmosphere, when compared with LFT, is influenced by two other factors with non-natural origin. One is the high enrichment and elemental concentrations of Mo. In Freitas et al. [39], it is 
referred the strong association with $\mathrm{U}$ in a compositional profile that could fit a number of uranium processing operations in north America. Mo is also present in LFT, but in much less amount. The other common enriched element in MBL is $\mathrm{Sb}$. The two common elements put in evidence the possibility of aerosol co-existence and reflection of the same air masses origins in north Atlantic atmosphere at different altitudes.

Acknowledgments The authors gratefully acknowledge Prof. Paulo Fialho and Dr. Filipe Barata (Group of Chemistry and Physics of the Atmosphere, Department of Agricultural Sciences, University of Azores, Portugal) for filter availability and spot identification. We also acknowledge Ms. Isabel Dionísio (ITN) for helping in the experiments. This research was partially supported by a $\mathrm{PhD}$ grant (financed by Fundação para a Ciência e Tecnologia, Portugal).

\section{References}

1. Astitha M, Kallos G, Spyrou C, O'Hirok W, Lelieveld J, van der Denier Gon HAC (2010) Atmos Chem Phys Discuss 10: 5185-5231

2. Biegalski SR, Villareal TA (2005) J Radioanal Nucl Chem 263: 767-772

3. Gregory K, Webster C, Durk S (1996) Energy Policy 24:655-664

4. Hauck H (1998) Toxicol Lett 96:269-276

5. Kanakidou M (2007) In: Mellouki A, Ravishankara AR (eds) Regional climate variability and its impacts in the mediterranean area. Springer, New York

6. Ramanathan V, Ramana MV, Roberts G, Kim D, Corrigan C, Chung C (2007) Nature. doi:10.1038/nature06019

7. WHO (2002) World health report: reducing risks, promoting healthy life. World Health Organization, Geneva

8. Charlson RJ, Heintzenberg J (1994) In: Charlson RJ, Heintzenberg J (eds) Aerosol forcing of climate. Wiley, Chichester

9. Horvat H (1996) Atmospheric aerosols-editorial. J Aerosol Sci 27: 355-357

10. IPCC (2001) In: Houghton JT (ed) Climate change, 2001: the scientific basis. Cambridge University Press, Cambridge

11. Lapina K, Honrath RE, Owen RC, Val Martin M, Pfister G (2006) Evidence of significant large-scale impacts of boreal fires on ozone levels in the midlatitude northern hemisphere free troposphere. Geophys Res Lett 33:L10815(4 pp)

12. Albrecht BA, Bretherton CS, Johnson D, Scubert WH, Frisch AS (1995) The Atlantic stratocumulus transition experiment-ASTEX. Bull Am Meteorol Soc 76:889-904

13. Honrath RE, Owen RC, Martin MV, Reid JS, Lapina K, Fialho P, Dziobak MP, Kleiss J, Westphal DL (2004) Regional and hemispheric impacts of anthropogenic and biomass burning emissions on summertime $\mathrm{CO}$ and $\mathrm{O} 3$ in the north Atlantic lower free troposphere. J Geophys Res 109:D24310, pp 17

14. Brasseur GP, Solomon S (2005) Aeronomy of the middle atmosphere, chemistry and physics of the stratosphere and mesosphere series-atmospheric and oceanographic sciences library. Springer, New York

15. Kanakidou M (2005) Particles of human origin extinguish natural solar irradiance in the climate system (PHOENICS) - synthesis and integration report. University of Crete, Crete

16. Zhang X, Zhuang G, Chen J, Xue H (2005) Chin Sci Bull 50: 738-744

17. Walsh JJ, Steidinger KA (2001) J Geophys Res 106:1159711692
18. Diaz AM, Diaz JP, Exposito FJ, Hernandez-Leal PA, Savoie D, Querol X (2006) J Atmos Chem 53:63-90

19. Prospero JM (2007) In: Mellouki A, Ravishankara AR (eds) African Dust: Its Large-Scale Transport over the Atlantic Ocean and its Impact on the Mediterranean Region. Springer, New York

20. Almeida SM, Freitas MC, Pio CA (2008) J Radioanal Nucl Ch 276:161-165

21. Coz E, Gomez-Moreno FJ, Pujadas M, Casuccio GS, Lersch TL, Artinano B (2009) Atmos Environ 43:1850-1863

22. Kang S, Mayewskia PA, Yan Y, Qin D, Yao T, Ren J (2003) Atmos Environ 37:4823-4835

23. Textor C, Graf HF, Timmreck C, Robock A (2003) In: Granier C, Rives C, Artaxo P (eds) Emissions from volcanoes. Kluwer, Dordrecht

24. Honrath RE, Owen RC, Val Martin M, Reid JS, Lapina K, Fialho P, Dziobak MP, Kleissl J, Westphal DL (2004) J Geophys Res. doi:10.1029/2004JD005147

25. Saarikoski SK, Sillanpää MK, Saarnio KM, Hillamo RE, Pennanen AS, Salonen RO (2008) Water Air Soil Pollut 191: 265-277

26. Alvesa C, Oliveira T, Pio C, Silvestre AJD, Fialho P, Barata F, Legrand M (2007) Atmos Environ 41:1359-1373

27. Holmes CW, Miller R (2004) Appl Geochem 19:1189-1200

28. Hoornaert S, Godoi MRH, Van Grieken R (2003) J Atmos Chem 46:271-293

29. Fialho F, Freitas MC, Barata F, Vieira BJ, Hansen ADA, Honrath RE (2006) Aerosol Sci 37:1497-1506

30. De Corte F (1987) The k0-standardization method-A move to the optimization of neutron activation analysis (Aggrege Thesis). Institute of Nuclear Sciences, University of Gent, Gent

31. De Corte F (2001) J Radioanal Nucl Chem 248:13-20

32. Freitas MC, Martinho E (1989) Anal Chim Acta 219:317-322

33. Freitas MC (1993) The development of k0-standardization neutron activation analysis with counting using a low energy photon detector. PhD Thesis, Institute of Nuclear Sciences. University of Gent, Gent

34. Blaauw M (2007) Software for single-comparator instrumental neutron activation analysis - the k0-IAEA program manual for version 3.21. International Atomic Energy Agency, Vienna, Austria, and Delft University of Technology, Delft

35. Vieira BJ, Soares PM, Prudencio MI, Freitas MC, Rodrigues AF (2004) Geociencias Rev Univ Aveiro 16:5-14

36. Almeida SM, Reis MA, Freitas MC, Pio CA (2003) Nucl Instr Meth B 207:434-446

37. Draxler RR, Rolph GD (2003) HYSPLIT (HYbrid Single-Particle Lagrangian Integrated Trajectory) Model access via NOAA ARL READY Website, NOAA Air Resources Laboratory, Silver Spring, MD. http://www.arl.noaa.gov/ready/hysplit4.html. Accessed 21 Jan 2011

38. Lai S, Springer N, Münz J, Hoffmann T (2007) Nucl Atmos Aeros 2000:1055-1059

39. Freitas MC, Pacheco AMG, Dionísio I, Vieira BJ (2009) In: Kim YJ, Platt U, Gu MB, Iwahashi H (eds) Aerosol concentrations and remote sources of airborne elements over Pico mountain, Azores, Portugal-environmental monitoring. Springer, Dordrecht

40. Xia L, Gao Y (2010) Mar Chem 119:77-90

41. Badar M, Ghauri M, Mirza I, Richter R, Dutkiewicz VA, Rusheed A, Khan AR, Husain L (2001) Chemosphere 3:51-63

42. Zhu L, Chen L, Yang X, Du J, Zhang Y (2004) Chin J Geochem 23(1):26-36

43. Ölmez I, Güllü G, Aras NK, Keskin SS (2004) J Radioanal Nucl Chem 259:157-162

44. Vieira BJ, Biegalski SR, Freitas MC, Landsberger S (2006) J Radioanal Nucl Chem 270:55-62

45. Prospero JM (1999) J Geophys Res 104:15-917

46. Zhang L (2010) Front Environ Sci Engin China 4:20-29 